\title{
Livedoid vasculopathy: fast involution after anticoagulant and hyperbaric oxygen therapy
}

\author{
Vasculopatia livedoide: rápida involução com câmara hiperbárica e terapia anticoagulante
}

\author{
Patricia Weinschenker Bollmann ${ }^{1}$, Andréa Kazumi Shimada², Nilceo Schwery Michalany ${ }^{4}$, \\ Ana Rita de Araújo Burgos Manhani ${ }^{3}$, Auro del Giglio ${ }^{2}$
}

\begin{abstract}
The livedoid vasculopathy is a rare condition characterized by the presence of recurrent painful ulcers in distal extremities of lower limbs. Histologically there is thickness of dermal vessels, occlusion of its light by fibrin thrombi associated with minimal inflammatory infiltrate. It might occur as an isolated condition or be associated with an underlying systemic disease, including coagulation and collagen disorders, or neoplasms. Because it is a rare disease there is no consensus for its treatment. We report a case of a 41-year-old man with painful ulcers in the lower extremities. We did not find any associated diseases. The lesions improved dramatically after treatment with anticoagulant and hyperbaric therapy. We concluded that anticoagulation associated with hyperbaric oxygenation may be benefit for the treatment of patients with livedoid vasculopathy. However, further studies should be done with a larger population to confirm our results.
\end{abstract}

Keywords: Vasculitis; Lower extremity; Leg ulcer; Anticoagulants; Hyperbaric oxigenation; Case reports

\section{RESUMO}

Avasculopatia livedoideé uma doença que se caracteriza pela presença de úlceras dolorosas recorrentes localizadas nas extremidades distais dos membros inferiores. Histologicamente, apresenta-se com espessamento dos vasos da derme, oclusão de sua luz por trombos de fibrina, associados a um mínimo infiltrado inflamatório. Pode se apresentar isoladamente ou em associação a trombofilias, desordens do colágeno ou doenças neoplásicas. Por ser uma entidade rara, não há consenso sobre seu tratamento. Relatamos 0 caso de um paciente de 41 anos, do sexo masculino, com úlceras dolorosas de membros inferiores. Nenhum fator associado foi encontrado. Houve dramática regressão do quadro após instituição de terapia anticoagulante concomitante à aplicação de sessões de câmara hiperbárica. Concluímos que a terapia anticoagulante associada a sessões de câmara hiperbárica parece ser benéfica na vasculopatia livedoide; entretanto, sua aplicação em maior número de pacientes faz-se necessária para confirmarmos nossos resultados.

Descritores: Vasculite; Extremidade inferior; Úlcera da perna; Anticoagulantes; Oxigenação hiperbárica; Relatos de casos

\section{INTRODUCTION}

Livedoid vasculopathy is a rare idiopathic disease. It is characterized by painful purpuric skin lesions, acute and recurrent which become ulcers and progress to white atrophic lesions ${ }^{(1)}$.

Generally, these lesions are located bilaterally on the distal extremities of the lower limbs, being more common in young adult women, and are aggravated in summer time. For this reason, they are also called vasculitis with summer ulcerations ${ }^{(2,3)}$.

It is histologically characterized by hyaline vascular alterations in the sub-intima, leakage of erythrocyte and fibrinous substance without evidence of leukocytoclastic vasculitis. Thrombosis of the dermal vessels and tissular ischemia may also occur ${ }^{(1)}$.

The pathogenesis of livedoid vasculopathy is unknown. It might have the participation of mechanisms operating in the microcirculation with endothelial changes and formation of occlusive thrombus in the dermal vessels usually associated to thrombophilia ${ }^{(2,4)}$.

\footnotetext{
'Hematology and Bone Marrow Transplantation, Hospital Israelita Albert Einstein - HIAE - São Paulo (SP), Brazil.

${ }^{2}$ Faculdade de Medicina do ABC - FMABC - Santo André (SP), Brazil.

${ }^{3}$ Hospital Israelita Albert Einstein - HIAE - São Paulo (SP), Brazil; Faculdade Medicina ABC - FMABC - Santo André (SP), Brazil.

${ }^{4}$ Universidade Federal de São Paulo - UNIFESP - São Paulo (SP), Brazil.

Corresponding author: Patricia Weinschenker Bollmann - Centro de Oncologia e Hematologia - HIAE - Avenida Albert Einstein, $627 / 701$ - Morumbi - CEP 05651-901 - São Paulo (SP), Brasil - Tel.: (11) 2151-0240 - e-mail: patriciawb@terra.com.br

Received on: April 30, 2010 - Accepted on: August 11, 2010

The authors declare no conflict of interests.
} 
In the majority of cases described in the literature there is an association with thrombotic abnormalities, disorders of the connective tissue ${ }^{(5)}$, hematological neoplasms ${ }^{(6)}$ and solid tumors ${ }^{(1)}$.

Because it is a rare disease there is not a defined consensus on the best treatment for it. However, platelet antiaggregants and anticoagulants have been used in several literature series ${ }^{(2,4,6)}$.

We report a case of livedoid vasculopathy that had a fast regression of the skin picture after performing an anticoagulant and hyperbaric oxygen therapy.

\section{CASE REPORT}

A 41-year-old man presented confluent purpuric and painful lesions in the distal extremities of the lower limbs which progressed to ulcers (Figure 1). The biopsy showed thickness of the vessel walls, vascular occlusion by thrombi and deposits of eosinophilic material (Figures 2A and 2B).

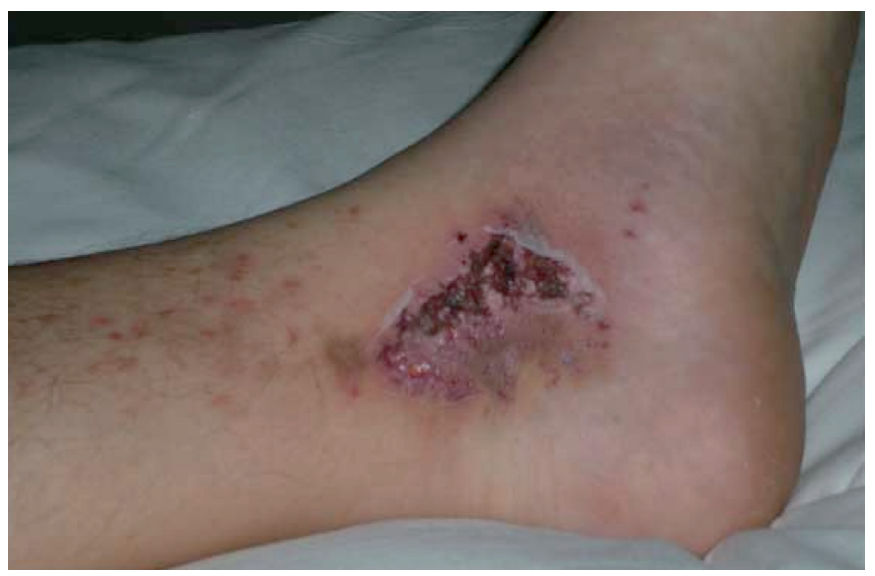

Figure 1. Confluent erythematous lesions in lower limbs that progressive to ulcer
Possible factors associated to this clinical picture such as prothrombotic factors, collagenosis and neoplasic diseases were investigated.

The investigation for thrombophilia was negative because we did not find evidences of factor V Leiden mutation or mutant prothrombine. The dosage of of the antithrombine III was $88 \%$ (80 to $120 \%)$; protein $\mathrm{S}$ total functioning, $82 \%$ (6 to $124 \%$ ); protein $\mathrm{S}$ free antigen, $80 \%$ (50 to $150 \%$ ); C protein, $111 \%$ (70 to $130 \%)$; resistance to C activated protein, $4.7(\mathrm{nl}>2.1)$; lupus anticoagulant, negative; $\operatorname{IgG}$ anticardiolipin, 2.8 GPL (nl < 15 GPL); IgM anticardiolipin, 3,4 MPL ( $\mathrm{nl}<12.5 \mathrm{MPL}$ ); homocysteine, $10.9 \mathrm{micromol} / \mathrm{L}$ (5 to $15 \mathrm{micromol} / \mathrm{L}$ ); factor XII, $82 \%$ (50 to $150 \%$ ); factor VIII, $89.4 \%$ (50\% to $150 \%$ ); fibrinogen, $467 \mathrm{mg} / \mathrm{dL}$ (200 to $400 \mathrm{mg} / \mathrm{dL}$ ).

The rheumatological profile included the investigation of crioglobulin that was negative; rheumatoid factor, < $15 \mathrm{UI} / \mathrm{mL}(\mathrm{nl}<15 \mathrm{UI} / \mathrm{ml})$; FAN (nucleus/nucleolus/cytoplasm/mitotic system/ metaphysical plate), non-reagent; non-reagent ANCA; anti-La/SS-B; anti LA/SS-A and anti-Sm were all negatives.

Complement dosages were within normality: total 94\% (90 to $94 \%$ ); C3, $125 \mathrm{mg} / \mathrm{dL}$ (90 to $180 \mathrm{mg} / \mathrm{dL}$ ); C4, $30.3 \mathrm{mg} / \mathrm{dL}$ (10 to $40 \mathrm{mg} / \mathrm{dL}$ ). A computed tomography of thorax and abdomen was also performed, but no alteration was found. When admitted to the hospital the patient had been using pentoxifyline and ASA and he has presented clinical worsening.

The medications were suspended and the patient was submitted to anticoagulant therapy with low molecular weight heparin, $2 \mathrm{mg} / \mathrm{kg}$ dose per day, with simultaneous warfarin until it reached INR over 2.0, and at the same time, submitted to ten applications of

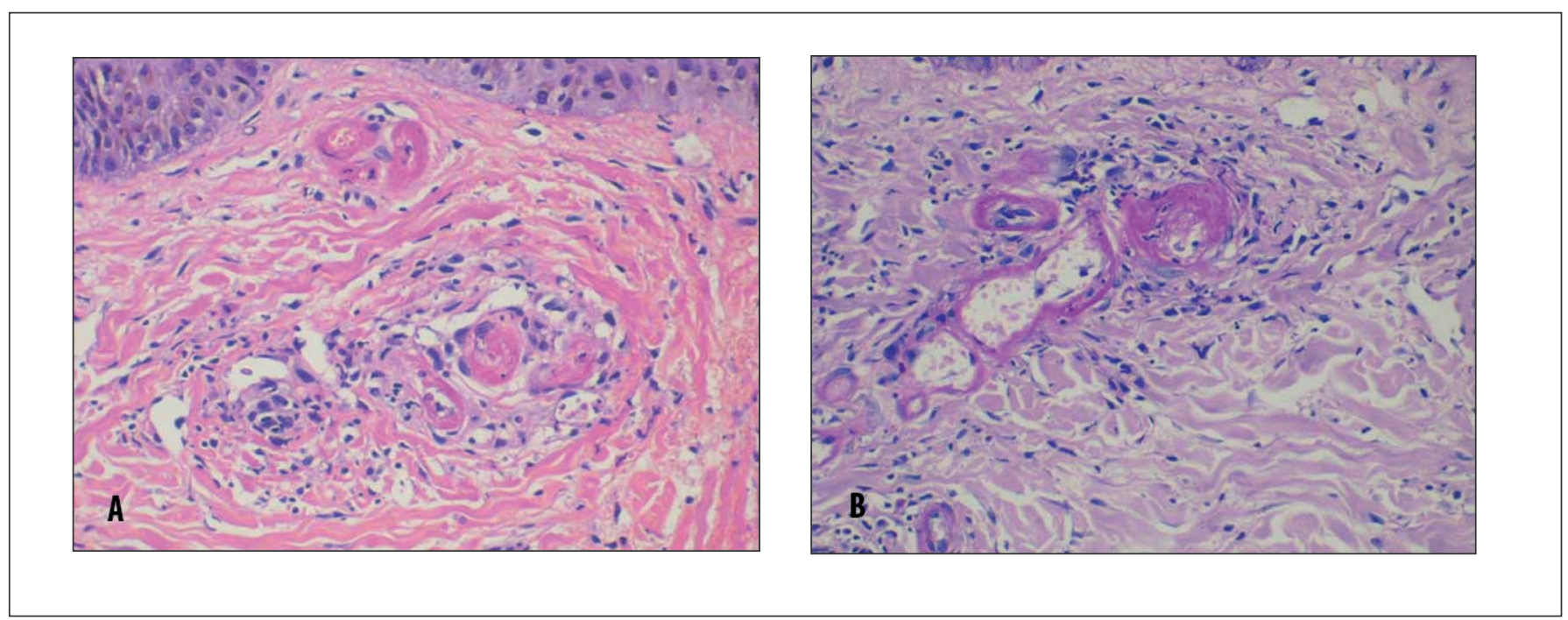

Figure 2. Derma presenting several capillaries with walls and thrombi composed with fibrin and eosinophilic substance. Yet there is a small leakage of perivascular inflammatory cells. (A) Hematoxylin-eosin; (B) PAS 
hyperbaric oxygen therapy. There was a fast clinical response in one week with control of the painful picture and regression of lesions which become crusts (Figure 3).

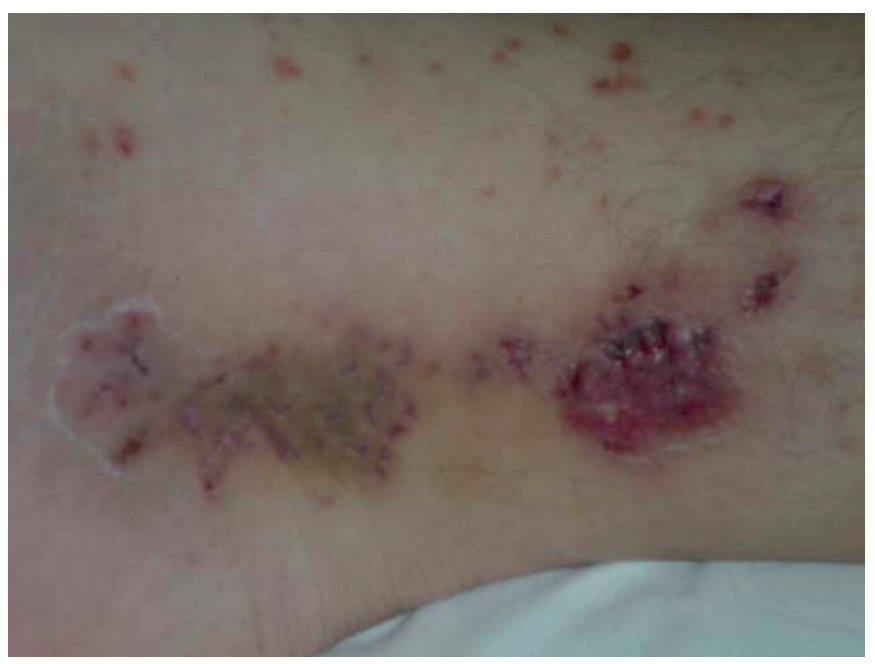

Figure 3. Delimitation of the process with formation of crusts

\section{DISCUSSION}

Livedoid vasculopathy is an uncommon disease. It was first described as an idiopathic cutaneous vasculopathy by Bard and Winkelmann in $1967^{(7)}$. In the literature we found only case reports on it, and in most descriptions there were associations with thrombophilic states, mainly with factor V Leiden mutations, mutant prothrombine, antiphospholipid syndrome and hyperhomocysteinemia ${ }^{(2,6-16)}$. However, in our patient, after an extensive investigation, we did not find any thrombophilia, collagenosis or neoplasm as a cause.

In the cases reported in the literature we also did not find a consensus for treatment, although the anticoagulant therapy with low weight heparin or with warfarin have been used in most of them ${ }^{(2)}$. The length of the disease is also not specified in the literature, and in almost all cases, the clinical condition associated with the livedoid vasculopathy was the main determinant of the disease duration. Some patients who had the anticoagulant therapy suspended, because of its suspension or not, presented a recurrent picture and they had responded after the reintroduction of the anticoagulant ${ }^{(2)}$.

In our study, in relation to the use hyperbaric oxygen therapy, it was demonstrated a rapid control of the clinical picture. Two patients with livedoid vasculopathy described by Yang et al. had responded to hyperbaric oxygen therapy after having failed multiple experiments using other therapeutic modalities ${ }^{(17)}$.
Thus, when facing a picture of livedoid vasculopathy, it is important to investigate the possible associated causes. Anticoagulation constitutes a significant strategy for the treatment, however, its length remains unknown.

The success of the treatment of our patient was achieved with a combined therapy (anticoagulation and hyperbaric oxygen therapy) what suggests that such therapy may be benefit for patients with livedoid vasculopathy.

\section{ACKNOWLEDGEMENT}

We would like to thank Denise Pasqualin, pathologist of Hospital Israelita Albert Einstein (HIAE).

\section{REFERENCES}

1. Hairston BR, Davis MD, Pittelkow MR, Ahmed I. Livedoid vasculopathy: further evidence for procoagulant pathogenesis. Arch Dermatol. 2006;142(11):1413-8.

2. Browning CE, Callen JP. Warfarin therapy for livedoid vasculopathy associated with cryofibrinogenemia and hyperhomocysteinemia. Arch Dermatol. 2006;142(1):75-8.

3. Amato L, Chiarini C, Berti S, Massi D, Fabbri P. Idiopathic atrophie blanche. Skinmed. 2006;5(3):151-4.

4. Deng A, Gocke CD, Hess J, Heyman M, Paltiel M, Gaspari A. Livedoid vasculopathy associated with plasminogen activator inhibitor-1 promoter homozygosity $(4 \mathrm{G} / 4 \mathrm{G})$ treated successfully with tissue plasminogen activator. Arch Dermatol. 2006;142(11):1466-9.

5. Mimouni D, Ng PP, Rencic A, Nikolskaia OV, Bernstein BD, Nousari HC. Cutaneous polyarteritis nodosa in patients presenting with atrophie blanche. $\mathrm{Br} \mathrm{J}$ Dermatol. 2003;148(4):789-94.

6. Davis MD, Wysokinski WE. Ulcerations caused by livedoid vasculopathy associated with a prothrombotic state: Response to warfarin. J Am Acad Dermatol. 2008;58(3):512-5.

7. McCalmont CS, McCalmont TH, Jorizzo JL, White WL, Leshin B, Rothberger H. Livedo vasculitis: vasculitis or thrombotic vasculopathy? Clin Exp Dermatol. 1992;17(1):4-8.

8. Hairston BR, Davis MD, Gibson LE, Drage LA. Treatment of livedoid vasculopathy with low-molecular-weight heparin: report of 2 cases. Arch Dermatol. 2003;139(8):987-90.

9. Magy N, Algros MP, Racadot E, Gil H, Kantelip B, Dupond JL. [Liveoid vasculopathy with combined thrombophilia: efficacy of iloprost]. Rev Med Interne. 2002;23(6):554-7. French

10. Biedermann T, Flaig MJ, Sander CA. Livedoid vasculopathy in a patient with factor V mutation (Leiden). J Cutan Pathol. 2000;27(8):410-2.

11. Grasland A, Crickx B, Blanc M, Pouchot J, Vinceneux P. [Livedoid vasculopathy (white atrophy) associated with anticardiolipin antibodies]. Ann Med Interne (Paris). 2000;151(5):408-10. French.

12. Calamia KT, Balabanova M, Perniciaro C, Walsh JS. Livedo vasculitis and the factor V Leiden mutation: additional evidence for abnormal coagulation. J Am Acad Dermatol. 2002;46(1):133-7.

13. Kavala M, Kocaturk E, Zindanci I, Turkoglu Z, Altintas S. A case of livedoid vasculopathy associated with factor $\mathrm{V}$ Leiden mutation: successful treatment with oral warfarin. J Dermatolog Treat. 2008;19(2):121-3.

14. Boyvat $A$, Kundakçi N, Babikir MO, Gürgey E. Livedoid vasculopathy associated with heterozygous protein C deficiency. Br J Dermatol. 2000;143(4):840-2. 
15. Meiss F, Marsch WC, Fischer M. Livedoid vasculopathy. The role of hyperhomocysteinemia and its simple therapeutic consequences. Eur J Dermatol. 2006;16(2):159-62.

16. Irani-Hakime NA, Stephan F, Kreidy R, Jureidini I, Almawi WY. Livedoid vasculopathy associated with combined prothrombin G20210A and factor V
(Leiden) heterozygosity and MTHFR C677T homozygosity. Thromb Thrombolysis. 2008;26(1):31-4.

17. Yang $\mathrm{CH}$, Ho HC, Chan YS, Liou LB, Hong HS, Yang LC. Intractable livedoid vasculopathy successfully treated with hyperbaric oxygen. $\mathrm{Br} J$ Dermatol. 2003;149(3):647-52. 